\title{
Pengembangan Perangkat Pembelajaran Matematika Dengan Pendekatan Realistik dalam Model Pembelajaran Berbasis Masalah untuk Siswa Kelas VII SMP
}

\author{
Nenny Indrawati \\ Universitas Sulawesi Barat, \\ e-mail: nennyindrawati1412@gmail.com
}

\begin{abstract}
Abstrak
Penelitian ini adalah penelitian pengembangan dengan ujicoba terbatas yang bertujuan untuk mengembangkan perangkat pembelajaran dengan pendekatan realistik dalam model pembelajaran berbasis masalah yang meliputi Buku Siswa, Lembar Kegiatan Siswa, dan Rencana Pelaksanaan Pembelajaran. Subjek penelitian ini adalah siswa kelas VII 2 SMP Negeri 2 Makassar. Prosedur pengembangan yang digunakan dalam penelitian ini adalah model Thiagarajan atau model 4-D. Perangkat pembelajaran yang dikembangkan, telah divalidasi, dan mengalami revisi sebanyak 2 kali sehingga didapatkan hasil yang maksimal dan layak untuk digunakan. Hasil dari ujicoba terbatas menunjukkan bahwa perangkat pembelajaran matematika dengan pendekatan realistik dalam model pembelajaran berbasis masalah bersifat efektif dan praktis, yaitu (1) skor rata-rata siswa pada tes hasil belajar yaitu 70,52 dari skor ideal 100 dengan standar deviasi 15,91 dengan siswa yang tuntas belajar sebesar 70,00\% atau 28 orang; (2) aktivitas siswa dan aktivitas guru menunjukkan kecenderungan yang positif; (3) pengelolaan kegiatan pembelajaran matematika dengan pendekatan kontekstual umumnya terlaksana dengan baik dengan persentase rata-rata keterlaksanaan aspek-aspek sebesar 87,5\%; dan (4) umumnya siswa memberikan respons positif terhadap perangkat pembelajaran yang digunakan dengan persentase sebesar $90,00 \%$.
\end{abstract}

Kata kunci: Pengembangan Perangkat Pembelajaran, Model Pembelajaran Berbasis Masalah, Pendekatan Realistik

\section{A. PENDAHULUAN}

Pendidikan memiliki pengaruh yang sangat besar bagi perkembangan peradaban manusia. Oleh karena itu, selalu diperlukan pembaharuan penyelenggaraan pendidikan untuk mengimbangi pesatnya laju perubahan dunia. Dewasa ini, pemerintah telah berupaya mengembangkan sistem pendidikan di Indonesia agar dapat sejajar dengan mutu pendidikan internasional. Penyempurnaan kurikulum dari tahun ke tahun tentu saja berimplikasi pada paradigma pembelajaran matematika agar sesuai dengan tuntutan kurikulum.

Beberapa model dan pendekatan pembelajaran telah berhasil dikembangkan oleh para pakar pendidikan untuk menjadi acuan yang dapat digunakan dalam proses pembelajaran. Namun, model pembelajaran langsung dengan metode ceramah yang mana proses pelaksanaannya berpusat pada guru, masih populer diterapkan di sekolah-sekolah karena dianggap efisiensi waktu pembelajaran dapat diperoleh. Hal ini jugalah yang terjadi pada proses pembelajaran matematika di SMPN 2 Makassar. Berdasarkan hasil wawancara dan observasi penulis pada RPP yang telah dibuat oleh guru mata pelajaran yang bersangkutan, maka diketahui 
bahwa dalam proses pembelajaran guru lebih sering menggunakan model pembelajaran langsung dengan pendekatan pembelajaran yang tidak ditetapkan secara jelas pada siswa dan sangat jarang menerapkan model maupun pendekatan pembelajaran yang lain, sehingga rasa jenuh pada siswa dapat saja terjadi karena model pembelajaran yang monoton.

Dengan adanya kondisi seperti diungkapkan di atas maka seorang guru dalam proses belajar mengajar perlu menggunakan suatu pendekatan, model, dan teknik mengajar yang bisa menumbuhkan kembali minat siswa untuk mempelajari matematika dengan memberikan masalah yang membuatnya tertantang untuk menyelesaikannya bukan justru menghindarinya.

Pendekatan realistik dengan model pembelajaran berbasis masalah dianggap mampu memberikan pelajaran yang bermakna bagi siswa, sesuai dengan pendapat Jenning dan Dunne (1999) yang mengungkapkan bahwa matematika menjadi sulit dipelajari oleh siswa karena pembelajaran matematika kurang bermakna. Pembelajar dihadapkan pada situasi pemecahan masalah dan menyelesaikannya secara berkelompok sehingga ada pertukaran ide secara bebas antar siswa dan kerja sama dapat terjalin dengan baik. Dalam hal ini, guru hanya berperan memfasilitasi terjadinya proses belajar dan memonitor proses pemecahan masalah.

Untuk melaksanakan pembelajaran matematika, diperlukan perangkat yang dapat mempermudah siswa dalam memahami pelajaran matematika. Oleh karena itu penulis melakukan penelitian dengan mengembangkan perangkat pembelajaran matematika. Judul penelitian ini adalah "Pengembangan Perangkat Pembelajaran Matematika dengan Pendekatan Realistik dalam Model Pembelajaran Berbasis Masalah Untuk Siswa Kelas VII SMP”

\section{B. METODE PENELITIAN}

\section{Jenis Penelitian}

Jenis penelitian ini adalah penelitian pengembangan yakni pengembangan perangkat pembelajaran, yang terdiri atas (1) Buku Siswa (BS), (2) Lembar Kerja Siswa (LKS), dan (3) Rencana Pelaksanaan Pembelajaran (RPP).

\section{Subjek Penelitian}

Penelitian ini dilaksanakan Pada Siswa Kelas VII SMPN 2 Makassar. Subjek penelitian adalah Siswa kelas $\mathrm{VII}_{2}$, dengan jumlah siswanya 40 orang, yang terdiri dari 20 orang siswa pria dan 20 orang siswa wanita.

\section{Fokus Penelitian}

Fokus penelitian ini adalah bagaimana cara menghasilkan perangkat pembelajaran berupa buku siswa, RPP, dan LKS yang valid, efektif dan praktis.

Data, Sumber data, Instrumen, dan Prosedur pengambilan data

Adapun data, sumber data, instrumen, dan prosedur pengambilan data dicantumkan pada tabel berikut:

Data, sumber data, instrumen dan prosedur pengambilan data

\begin{tabular}{lllll}
\hline No. & \multicolumn{1}{c}{ Data } & Sumber data & Instrumen & Prosedur pengambilan data \\
\hline 1 & $\begin{array}{l}\text { Skor Tes hasil } \\
\text { belajar }\end{array}$ & Siswa & Soal Tes & $\begin{array}{l}\text { Tes diberikan pada akhir } \\
\text { pembelajaran }\end{array}$ \\
\hline
\end{tabular}




\section{JURNAL SAINTIFIK VOL.3 NO.1, JANUARI 2017}

\begin{tabular}{lllll}
\hline No. & \multicolumn{1}{c}{ Data } & Sumber data & Instrumen & Prosedur pengambilan data \\
\hline 2 & $\begin{array}{l}\text { Kemampuan guru } \\
\text { mengelolah } \\
\text { pembelajaran } \\
\text { Aktivitas guru }\end{array}$ & Guru & Angket & $\begin{array}{l}\text { Angket diisi setiap } \\
\text { pertemuan }\end{array}$ \\
4 & Akivitas Siswa & Siswa & Angket & $\begin{array}{l}\text { Angket diisi setiap } \\
\text { pertemuan } \\
\text { Angket diisi setiap } \\
\text { pertemuan } \\
\text { Angket diisi diakhir proses } \\
\text { pembelajaran }\end{array}$ \\
\hline
\end{tabular}

\section{Prosedur Penelitian}

1) Tahap persiapan

a. Mengembangkan perangkat pembelajaran yaitu Buku Siswa (BS), Lembar Kegiatan Siswa (LKS), Rencana Pelaksanaan Pembelajaran (RPP).

b. Membuat tes hasil belajar siswa, lembar observasi untuk mengamati aktivitas siswa, aktivitas guru dan pengelolaan pembelajaran di dalam kelas.

c. Membuat angket untuk mengetahui respon siswa tentang perangkat pembelajaran yang dikembangkan dengan model pembelajaran berbasis masalah.

2) Tahap Pelaksanaan

a. Menjelaskan garis besar materi yang dipelajari.

b. Membagi siswa ke dalam kelompok kecil dengan memperhatikan tingkat kognitif yang dicapai pada pokok bahasan sebelumnya.

c. Melaksanakan pembelajaran matematika dengan model berbasis masalah.

d. Selama proses pembelajaran berlangsung dilakukan pengamatan aktivitas siswa, guru dan kemampuan guru mengelola pembelajaran.

3) Tahap Analisis Data

Kegiatan pada tahap ini adalah menganalisis data yang diperoleh dari tahap pelaksanaan. Data yang akan dianalisis adalah data hasil belajar siswa.

\section{Teknik Analisis Data}

Berikut ini dikemukakan tentang analisis data kevalidan, kepraktisan dan keefektifan.

\section{Analisis Data Kevalidan Perangkat Pembelajaran}

Berdasarkan data hasil penilaian kevalidan perangkat pembelajaran oleh dua validator/ahli, yaitu orang yang dipandang ahli dalam bidang pendidikan matematika, dihitung nilai rata-rata $\mathrm{V}\left(\frac{-}{x}\right)$ dari V1 dan V2 dengan V1 = nilai rata-rata yang diperoleh dari validator pertama, $\mathrm{V} 2$ = nilai rata-rata yang diperoleh dari validator kedua.

Nilai V $(\bar{x})$ ini selanjutnya dikonfirmasikan dengan interval penentuan kategori validitas perangkat pembelajaran dengan pendekatan realistik, yaitu:

- Sangat Valid (SV) $: 3,5 \leq \bar{x} \leq 4$

- Valid (V) $: 2,5 \leq \bar{x}<3,5$

- Cukup Valid (CV) : $1,5 \leq \bar{x}<2,5$

- Tidak Valid (TV) : $\bar{x}<1,5$

Kriteria yang digunakan untuk memutuskan bahwa perangkat pembelajaran dengan pendekatan realistik yang terdiri dari Buku Siswa, LKS, RPP, dan Tes Hasil Belajar memiliki 
derajat validitas yang memadai adalah: nilai $\mathrm{V}(\bar{x})$ untuk keseluruhan aspek pada Buku Siswa, LKS, dan RPP minimal berada dalam kategori cukup valid.

\section{Analisis Data Keefektifan Perangkat Pembelajaran}

\section{a. Analisis Data Hasil Belajar Siswa}

Analisis dilakukan terhadap skor-skor yang diperoleh siswa dari tes hasil belajar yang diberikan setelah semua materi tuntas dibahas. Kriteria yang digunakan untuk menentukan skor adalah skala lima berdasarkan teknik kategorisasi standar yang ditetapkan oleh Departemen Pendidikan Nasional yaitu:

- Kemampuan $85 \%$ - 100\% atau skor 85 - 100 dikategorikan sangat tinggi

- Kemampuan 65\% - 84\% atau skor 65 - 84 dikategorikan tinggi

- Kemampuan 55\% - 64\% atau skor 55- 64 dikategorikan sedang

- Kemampuan 35\% - 54\% atau skor 35 - 54 dikategorikan rendah

- Kemampuan $0 \%$ - 34\% atau skor 0 - 34 dikategorikan sangat rendah

Pada materi Aritmetika Sosial, Kriteri Ketuntasan Minimal (KKM) yang harus dipenuhi oleh seorang siswa adalah 60. Jika seorang siswa memperoleh $S \geq 60$ maka siswa yang bersangkutan mencapai ketuntasan individu. Jika minimal 75\% siswa mencapai skor minimal 60, maka ketuntasan klasikal telah tercapai (KKM ditentukan oleh sekolah bersangkutan).

\section{b. Analisis Data Aktivitas Siswa}

Untuk mencari rata-rata frekuensi dan rata rata persentase waktu yang digunakan siswa melakukan aktivitas selama kerjasama dalam kelompok ditentukan melalui langkah-langkah berikut:

1. Hasil pengamatan aktivitas siswa untuk setiap indikator dalam satu kali pertemuan ditentukan frekuensinya dan dicari rata-rata frekuensinya. Selanjutnya, ditentukan frekuensi rata-rata dari rata-rata frekuensi untuk beberapa kali pertemuan.

2. Mencari persentase frekuensi setiap indikator dengan cara membagi besarnya frekuensi dengan jumlah frekuensi untuk setiap indikator. Kemudian hasil pembagian dikali 100\%. Selanjutnya dicari rata-rata persentase waktu untuk beberapa kali pertemuan dan dimasukkan dalam tabel rata-rata persentase.

Selanjutnya persentase waktu untuk setiap indikator dirujuk terhadap kriteria pencapaian waktu ideal aktivitas siswa yang tersaji pada tabel berikut ini:

\section{Kriteria Pencapaian Waktu Ideal Aktivitas Siswa}

\begin{tabular}{|c|c|c|c|c|}
\hline No & Kategori Aktivitas Siswa & Waktu Ideal & $\begin{array}{c}\text { Interval } \\
\text { Toleransi PWI } \\
(\%)\end{array}$ & Kriteria \\
\hline 1 & $\begin{array}{l}\text { Memperhatikan informasi dan } \\
\text { mencatat seperlunya }\end{array}$ & $13 \%$ dari WT & $8-18$ & \multirow{4}{*}{$\begin{array}{l}\text { Kategori } \\
(1),(2), \\
(3),(4),(6) \\
\text { dan (7) } \\
\text { harus } \\
\text { terpenuhi }\end{array}$} \\
\hline 2 & $\begin{array}{l}\text { Membaca LKS, materi } \\
\text { pelajaran atau buku siswa }\end{array}$ & $13 \%$ dari WT & $8-18$ & \\
\hline 3 & $\begin{array}{l}\text { Aktif berdiskusi dengan } \\
\text { teman }\end{array}$ & $20 \%$ dari WT & $15-25$ & \\
\hline 4 & Aktif terlibat dalam tugas & $26 \%$ dari WT & $21-31$ & \\
\hline
\end{tabular}




\section{JURNAL SAINTIFIK VOL.3 NO.1, JANUARI 2017}

\begin{tabular}{|c|l|c|c|c|}
\hline No & \multicolumn{1}{|c|}{ Kategori Aktivitas Siswa } & Waktu Ideal & $\begin{array}{c}\text { Interval } \\
\text { Toleransi PWI } \\
\text { (\%) }\end{array}$ & Kriteria \\
\hline 5 & $\begin{array}{l}\text { Mencatat apa yang } \\
\text { disampaikan teman }\end{array}$ & $7 \%$ dari WT & $2-12$ & $2-12$ \\
\hline 6 & $\begin{array}{l}\text { Mengajukan pertanyaan } \\
\text { kepada teman/guru }\end{array}$ & $7 \%$ dari WT & $2-12$ & $2-12$ \\
\hline 7 & $\begin{array}{l}\text { Menjawab/menanggapi } \\
\text { pertanyaan teman/guru }\end{array}$ & $\begin{array}{l}\text { Memberi bantuan penjelasan } \\
\text { kepada teman } \\
\text { membutuhkan }\end{array}$ & $7 \%$ dari WT \\
\hline 9 & $\begin{array}{l}\text { Kegiatan siswa di luar tugas, } \\
\text { misalkan tidak } \\
\text { memperhatikan penjelasan } \\
\text { guru, mengerjakan tugas mata } \\
\text { pelajaran lain, atau kegiatan } \\
\text { lain yang tidak berhubungan } \\
\text { dengan aktivitas KMB, } \\
\text { misalnya main, tidur, dsb. }\end{array}$ & $0 \%$ dari WT \\
\hline
\end{tabular}

Keterangan: PWI adalah persentase waktu indikator

WT adalah waktu tersedia pada setiap pertemuan

\section{c. Analisis Data Aktivitas Guru}

1. Mencari persentase frekuensi setiap indikator pada setiap pertemuan dengan cara membagi besarnya frekuensi dengan jumlah frekuensi untuk semua indikator. Kemudian hasil pembagian dikali $100 \%$.

2. Selanjutnya dicari rata-rata persentase waktu untuk beberapa kali pertemuan dan dimasukkan dalam tabel rata-rata persentase. Selanjutnya persentase waktu untuk setiap indikator dirujuk terhadap kriteria pencapaian waktu ideal aktivitas guru tersaji pada tabel berikut.

Kriteria pencapaian Waktu ideal Aktivitas Guru

\begin{tabular}{|c|c|c|c|c|}
\hline No & Kategori Aktivitas Guru & Waktu Ideal & $\begin{array}{c}\text { Interval } \\
\text { Toleransi PWI } \\
(\%) \\
\end{array}$ & Kriteria \\
\hline 1 & $\begin{array}{l}\text { Menginformasikan masalah } \\
\text { yang harus dikerjakan dalam } \\
\text { kelompok }\end{array}$ & $13 \%$ dari WT & $8-18$ & \multirow{4}{*}{$\begin{array}{c}\text { Kategori } \\
(1),(2),(3), \\
(4),(6) \\
\text { harus } \\
\text { dipenuhi }\end{array}$} \\
\hline 2 & $\begin{array}{l}\text { Meminta siswa mengerjakan } \\
\text { tugas lKS dengan bekerja } \\
\text { sama dalam kelompok }\end{array}$ & $13 \%$ dari WT & $8-18$ & \\
\hline 3 & $\begin{array}{l}\text { Memberi arahan agar siswa } \\
\text { selalu berada dalam tugas } \\
\text { kelompok }\end{array}$ & $13 \%$ dari WT & $8-18$ & \\
\hline 4 & $\begin{array}{l}\text { Mengontrol/berkeliling } \\
\text { memperhatikan kegiatan } \\
\text { setiap kelompok }\end{array}$ & $27 \%$ dari $\mathrm{WT}$ & $21-31$ & \\
\hline
\end{tabular}


JURNAL SAINTIFIK VOL 3 NO.1, JANUARI 2017

\begin{tabular}{|c|c|c|c|}
\hline 5 & $\begin{array}{l}\text { Memberi bantuan/bimbingan } \\
\text { pada siswa dalam aktivitas } \\
\text { pemecahan masalah dalam } \\
\text { kelompoknya }\end{array}$ & $20 \%$ dari $\mathrm{WT}$ & $15-25$ \\
\hline 6 & $\begin{array}{l}\text { Mengajukan pertanyaan yang } \\
\text { dapat merangsang siswa untuk } \\
\text { berpikir (membuka wawasan) }\end{array}$ & $7 \%$ dari $\mathrm{WT}$ & $2-12$ \\
\hline 7 & Memberi umpan balik & $7 \%$ dari $\mathrm{WT}$ & $2-12$ \\
\hline 8 & $\begin{array}{l}\text { Kegiatan di luar tugas, } \\
\text { misalnya ke luar kelas, } \\
\text { bercerita dengan guru lain dan } \\
\text { sebagainya. }\end{array}$ & $0 \%$ dari WT & $0-5$ \\
\hline
\end{tabular}

\section{d. Analisis Pengelolaan Pembelajaran}

Analisis dilakukan terhadap hasil penelitian dari satu pengamat yang mengamati kemampuan guru mengelola pembelajaran di kelas. Pengamatan dilakukan terhadap kemampuan guru melaksanakan tiap-tiap aspek dari sintaks pembelajaran kooperatif. Dari hasil pengamat selama empat kali pertemuan, ditentukan nilai rata-rata KG dari pertemuan pertama sampai pertemuan keempat. Nilai $\mathrm{KG}$ ini selanjutnya dikonfirmasikan dengan interval penentuan kategori validitas perangkat pembelajaran dengan pendekatan realistik, yaitu:

$3,50 \leq \overline{K G} \leq 4,00$ berarti sangat tinggi (ST)

$2,50 \leq \overline{K G}<3,50$ berarti tinggi (T)

$1,50 \leq \overline{K G}<2,50$ berarti cukup tinggi (CT)

$\overline{K G}<1,50$ berarti tidak tinggi (TT)

\section{a. Analisis Respons Siswa}

Kriteria yang ditetapkan untuk menyatakan bahwa para siswa memiliki respons positif terhadap perangkat pembelajaran realistik dengan model pembelajaran berbasis masalah adalah $50 \%$ dari mereka memberi respons positif terhadap minimal $70 \%$ jumlah aspek

\section{Analisis Data Kepraktisan Perangkat Pembelajaran.}

Data kepraktisan perangkat pembelajaran terdiri dari dua bagian, yaitu (1) data hasil penilaian kelayakan penggunaan perangkat pembelajaran dari empat orang ahli, dan (2) data dari keterlaksanaan pembelajaran secara umum dari satu pengamat. Dengan demikian untuk menganalisis data kepraktisan, dipertimbangkan kedua bagian tersebut sebagai berikut:

\section{HASIL DAN PEMBAHASAN}


JURNAL SAINTIFIK VOL.3 NO.1, JANUARI 2017

\section{Hasil Penelitian}

\section{Tahap Pembatasan}

\section{a. Analisis Kurikulum}

Berdasarkan analisis kurikulum yang dilakukan, maka diketahui materi pelajaran yang diajarkan pada semester ganjil antara lain bilangan bulat dan pecahan, bentuk aljabar, persamaan dan pertidaksamaan linear satu variabel, aritmetika sosial dan perbandingan.

\section{b. Analisis Siswa}

Ditinjau dari perkembangan kogintifnya, maka menurut Piaget siswa-siswa ini berada pada tahap operasi formal (11 tahun ke atas). Namun pada kenyataannya, siswa-siswa tersebut masih memerlukan benda konkret dalam mempelajari matematika. Oleh karena itu, dalam pembelajaran matematika perlu diawali dengan masalah realistik yang dekat dengan kehidupan sehari-hari siswa.

\section{c. Analisis Konsep}

Konsep utama yang diidentifikasi pada pengembangan perangkat pembelajaran ini adalah analisis konsep untuk materi aritmetika social dengan sub pokok bahasan adalah menghitung nilai keseluruhan dan nilai perunit, perhitungan dalam kehidupan sehari-hari.

\section{d. Analisis Tugas}

Dalam analisis tugas berdasarkan pokok bahasan aritmetika sosial diperoleh beberapa tugas-tugas yang diharapkan mampu mengarahkan kemampuan siswa untuk memahami materi pada pokok bahasan tersebut sehingga tujuan pembelajaran dapat tercapai.

\section{Tahap Perancangan}

Tahap ini bertujuan merancang prototipe perangkat pembelajaran. Hasil pada tahap perancangan (design) berupa tiga buah perangkat pembelajaran yaitu s, rencana pelaksanaan pembelajaran (RPP), buku siswa, lembar kerja siswa (LKS).

\section{Tahap Pengembangan}

\section{a. Penilaian para ahli}

Penilaian para ahli berarti validator menelaah semua perangkat yang telah dihasilkan (Draft 1). Hasil penilaian, analisis, dan revisi terhadap perangkat pembelajaran tersebut dikemukakan sebagai berikut.

\begin{tabular}{|c|c|c|c|}
\hline No. & Perangkat Pembelajaran & Rata-rata Total & Keterangan \\
\hline 1 & Buku Siswa & 3,40 & $\mathrm{~V}$ \\
\hline 2 & LKS & 3,40 & $\mathrm{~V}$ \\
\hline 3 & RPP & 3,33 & $\mathrm{~V}$ \\
\hline
\end{tabular}

Berdasarkan tabel di atas, dapat disimpulkan bahwa rata-rata penilaian atau hasil validasi dari para ahli pada perangkat pembelajaran yang dikembangkan yang meliputi Buku Siswa, LKS, dan RPP berada pada kategori "Valid" $(2,5 \leq \bar{x}<3,5)$. Hal ini berarti perangkat pembelajaran tersebut telah layak untuk diujicobakan, namun demikian perangkat-perangkat tersebut yang menurut saran para ahli masih perlu diperbaiki atau ditambahkan.

\section{b. Analisis Hasil Ujicoba}

Berdasarkan hasil ujicoba perangkat pembelajaran yang meliputi Buku Siswa, LKS, dan RPP terdapat beberapa revisi pada perangkat pembelajaran tersebut. Selain itu, diperoleh 
pula data hasil belajar siswa, data hasil pengamatan aktivitas siswa, data hasil pengamatan guru, data hasil pengamatan pengelolaan pembelajaran, dan respon siswa terhadap kegiatan pembelajaran matematika dengan pendekatan realistik dalam model pembelajaran berbasis masalah.

\section{Analisis Deskriptif Hasil Penelitian}

Berdasarkan hasil ujicoba perangkat pembelajaran yang meliputi buku siswa, LKS, dan RPP diperoleh data hasil tes belajar siswa, data hasil pengamatan aktivitas siswa, data hasil pengamatan aktivitas guru, data hasil pengamatan pengelolaan pembelajaran matematika realistik, dan respon siswa terhadap kegiatan pembelajaran matematika realistik. Hasil analisis masing-masing data sebagai berikut:

\section{Hasil tes belajar siswa}

Tes hasil belajar diberikan ke siswa untuk memperoleh informasi tentang penguasaan siswa terhadap materi yang telah diajarkan. Hasil analisis deskriptif secara kuantitatif penguasaan matematika setelah diberi tindakan pada tes hasil belajar dapat dilihat pada tabel berikut:

Statistik Skor Hasil Belajar Matematika Siswa Kelas VII 2 SMP Negeri 2 Makassar

\begin{tabular}{|c||c||}
\hline \multicolumn{1}{|c||}{ Variabel } & Nilai Statistik \\
\hline \hline Subjek Penelitian & 40 \\
\hline \hline Skor Ideal & 100 \\
\hline \hline Rata-rata & 70,52 \\
\hline \hline Standar Deviasi & 15,91 \\
\hline \hline Varians & 253,281 \\
\hline \hline Rentang Skor & 60 \\
\hline \hline Skor Maksimum & 100 \\
\hline \hline Skor Minimum & 40 \\
\hline \hline Jumlah Siswa yang Tuntas & 28 \\
\hline \hline
\end{tabular}

Jika skor hasil belajar dikelompokkan dalam lima kategori, maka diperoleh tabel distribusi frekuensi seperti berikut: 


\section{JURNAL SAINTIFIK VOL.3 NO.1, JANUARI 2017}

Distribusi Frekuensi dan Persentase Skor Hasil Belajar Matematika Siswa Kelas VII SMP Negeri 2 Makassar pada Tes Hasil Belajar

\begin{tabular}{|c|c|c|c|c|c|}
\hline No & \multicolumn{2}{|c|}{ Nilai } & Kategori & Frekuensi & Persentase \\
\hline 1 & \multicolumn{2}{|c|}{$0-34$} & Sangat Rendah & - & 0 \\
\hline 2 & \multicolumn{2}{|c|}{$35-54$} & Rendah & 7 & $17,5 \%$ \\
\hline \multirow{2}{*}{3} & \multirow{2}{*}{$55-64$} & $55-59$ & \multirow{2}{*}{ Sedang } & 5 & $12,5 \%$ \\
\hline & & $60-64$ & & 6 & $15 \%$ \\
\hline 4 & \multicolumn{2}{|c|}{$65-84$} & Tinggi & 12 & $30 \%$ \\
\hline 5 & \multicolumn{2}{|c|}{$85-100$} & Sangat Tinggi & 10 & $25 \%$ \\
\hline
\end{tabular}

Berdasarkan data di atas, perangkat pembelajaran matematika yang dikembangkan dengan pendekatan realistik dalam model pembelajaran berbasis masalah yang meliputi Buku Siswa, LKS, dan RPP layak digunakan.

\section{Data hasil pengamatan aktivitas siswa}

Hasil pengamatan terhadap aktivitas siswa secara ringkas dapat dilihat pada tabel berikut:

Tabel 5.6 Aktivitas Siswa Selama Kegiatan Pembelajaran

\begin{tabular}{|c|c|c|c|c|c|c|c|c|c|c|}
\hline \multirow{2}{*}{ Kategori } & \multicolumn{3}{|c|}{ Pertemuan } & \multicolumn{3}{c|}{$\begin{array}{c}\text { Persentase } \\
\text { Pertemuan }\end{array}$} & $\begin{array}{c}\text { Rata- } \\
\text { Rata } \\
\text { (\%) }\end{array}$ & $\begin{array}{c}\text { Interval } \\
\text { Toleransi } \\
(\mathbf{\%})\end{array}$ & $\begin{array}{c}\text { Waktu } \\
\text { Ideal } \\
\mathbf{( \% )}\end{array}$ & $\begin{array}{c}\text { Waktu } \\
\text { Ideal } \\
\text { (menit) }\end{array}$ \\
\hline & I & II & III & I & II & III & (1) \\
\hline 1 & 11 & 8 & 11 & 14,67 & 10,67 & 14,67 & 13,33 & $8-18$ & 13 & 6 \\
\hline 2 & 12 & 14 & 14 & 16,00 & 18,67 & 18,67 & 17,78 & $8-18$ & 13 & 6 \\
\hline 3 & 14 & 13 & 15 & 18,67 & 17,33 & 20,00 & 18,67 & $15-25$ & 20 & 9 \\
\hline 4 & 17 & 18 & 19 & 22,67 & 24,00 & 25,33 & 24,00 & $21-31$ & 26 & 12 \\
\hline 5 & 6 & 6 & 4 & 8,00 & 8,00 & 5,33 & 7,11 & $2-12$ & 7 & 3 \\
\hline 6 & 8 & 3 & 4 & 10,67 & 4,00 & 5,33 & 6,67 & $2-12$ & 7 & 3 \\
\hline 7 & 0 & 3 & 3 & 0 & 4,00 & 4,00 & 2,67 & $2-12$ & 7 & 3 \\
\hline 8 & 3 & 3 & 2 & 4,00 & 4,00 & 2,67 & 3,56 & $2-12$ & 7 & 3 \\
\hline 9 & 4 & 7 & 3 & 5,33 & 9,33 & 4,00 & 6,22 & $0-5$ & 0 & 0 \\
\hline Jumlah & 75 & 75 & 75 & 100 & 100 & 100 & & & 100 & 45 \\
\hline
\end{tabular}

Berdasarkan data persentase rata-rata aktivitas siswa dari tiga kali pertemuan diperoleh informasi bahwa siswa lebih aktif melakukan kegiatan pada kategori keempat yaitu aktif terlibat dalam tugas. Selain itu diperoleh informasi bahwa terdapat 8 kategori yang terpenuhi dari 9 kategori. Adapun kategori yang tidak memenuhi yaitu kategori kesembilan. Hal ini disebabkan karena rata-rata persentase waktu aktivitas siswa pada kategori tersebut tidak memenuhi kriteria batas toleransi pencapaian waktu ideal.

\section{Data hasil pengamatan aktivitas guru}


JURNAL SAINTIFIK VOL 3 NO.1, JANUARI 2017

berikut:

Data hasil pengamatan aktivitas guru selama tiga kali pertemuan disajikan dalam tabel

Tabel Aktivitas Guru Selama Kegiatan Pembelajaran.

\begin{tabular}{|c|c|c|c|c|c|c|c|c|c|c|}
\hline \multirow{2}{*}{ Kategori } & \multicolumn{3}{|c|}{ Pertemuan } & \multicolumn{3}{|c|}{$\begin{array}{c}\text { Persentase } \\
\text { Pertemuan }\end{array}$} & $\begin{array}{c}\text { Rata- } \\
\text { Rata } \\
\text { (\%) }\end{array}$ & $\begin{array}{c}\text { Interval } \\
\text { Toleransi } \\
\mathbf{( \% )}\end{array}$ & $\begin{array}{c}\text { Waktu } \\
\text { Ideal } \\
\mathbf{( \% )}\end{array}$ & $\begin{array}{c}\text { Waktu } \\
\text { Ideal } \\
\text { (menit) }\end{array}$ \\
\cline { 2 - 7 } & I & II & III & I & II & III & (m) \\
\hline 1 & 2 & 2 & 1 & 13,33 & 13,33 & 6,67 & 11,11 & $8-18$ & 13 & 6 \\
\hline 2 & 2 & 1 & 2 & 13,33 & 6,67 & 13,33 & 11,11 & $8-18$ & 13 & 6 \\
\hline 3 & 2 & 2 & 2 & 13,33 & 13,33 & 13,33 & 13,33 & $8-18$ & 13 & 6 \\
\hline 4 & 3 & 4 & 4 & 20 & 26,67 & 26,67 & 24,44 & $21-31$ & 27 & 12 \\
\hline 5 & 3 & 2 & 2 & 20 & 13,33 & 13,33 & 15,56 & $15-25$ & 20 & 9 \\
\hline 6 & 1 & 2 & 2 & 6,67 & 13,33 & 13,33 & 11,11 & $2-12$ & 7 & 3 \\
\hline 7 & 1 & 2 & 1 & 6,67 & 13,33 & 6,67 & 8,89 & $2-12$ & 7 & 3 \\
\hline 8 & 1 & 0 & 1 & 13,33 & 6,67 & 6,67 & 4,44 & $0-5$ & 0 & 0 \\
\hline Jumlah & 15 & 15 & 15 & 100 & 100 & 100 & & & 100 & 45 \\
\hline
\end{tabular}

Berdasarkan data tersebut, diperoleh informasi bahwa seluruh kategori pada aktivitas guru dapat terpenuhi. Sehingga kriteria yang telah ditetapkan pada sesuai dengan hasil analisis data aktivitas guru.

\section{Data hasil pengamatan pengelolaan pembelajaran matematika realistik}

Data hasil pengamatan pengelolaan pembelajaran selama tiga kali pertemuan disajikan dalam tabel berikut:

Pengelolaan Pembelajaran Matematika dengan Pendekatan Realistik

\begin{tabular}{|c|c|c|c|c|c|}
\hline \multirow{2}{*}{ ASPEK PENGAMATAN } & \multicolumn{3}{|c|}{ Pertemuan ke- } & \multirow{2}{*}{$\overline{K G}$} & \multirow{2}{*}{$\begin{array}{c}\mathrm{Ke} \\
\mathbf{t}\end{array}$} \\
\hline & 1 & 2 & 3 & & \\
\hline \multicolumn{6}{|l|}{ I. KEGIATAN BELAJAR MENGAJAR } \\
\hline \multicolumn{6}{|l|}{ A. KEGIATAN AWAL } \\
\hline \multicolumn{6}{|l|}{ Fase 1: Orientasi Siswa pada Masalah } \\
\hline 1. Mempersiapkan siswa untuk belajar. & 4 & 4 & 4 & 4 & ST \\
\hline 2. Menyampaikan materi yang akan dipelajari & 4 & 4 & 4 & 4 & ST \\
\hline $\begin{array}{l}\text { 3. Menjelaskan model pembelajaran yang akan dipakai } \\
\text { dalam pembelajaran }\end{array}$ & 3 & 2 & 3 & 2,7 & $\mathbf{T}$ \\
\hline 4. Memotivasi siswa & 4 & 3 & 4 & 3,7 & ST \\
\hline 5. Guru mengajukan masalah nyata terkait dengan materi. & 3 & 4 & 4 & 3,7 & ST \\
\hline 6. Guru meminta siswa untuk bertanya. & 3 & 4 & 3 & 3,3 & $\mathbf{T}$ \\
\hline 7. Guru menjawab / menanggapi pertanyaan dari siswa. & 4 & 4 & 3 & 3,7 & ST \\
\hline \multicolumn{4}{|l|}{ RATA-RATA KEGIATAN AWAL } & 3,6 & ST \\
\hline B. KEGIATAN INTI & & & & & \\
\hline Fase 2: Mengorganisir siswa untuk belajar & & & & & \\
\hline
\end{tabular}


JURNAL SAINTIFIK VOL.3 NO.1, JANUARI 2017

\begin{tabular}{|c|c|c|c|c|c|}
\hline \multirow{2}{*}{ ASPEK PENGAMATAN } & \multicolumn{3}{|c|}{ Pertemuan ke- } & \multirow{2}{*}{$\overline{K G}$} & \multirow{2}{*}{$\begin{array}{c}\mathrm{Ke} \\
\mathbf{t}\end{array}$} \\
\hline & 1 & 2 & 3 & & \\
\hline $\begin{array}{l}\text { 1.Guru mengorganisasikan siswa ke dalam } \\
\text { kelompoknya. }\end{array}$ & 4 & 4 & 4 & 4 & ST \\
\hline 2. Guru memberikan LKS kepada setiap siswa & 4 & 4 & 4 & 4 & ST \\
\hline $\begin{array}{l}\text { 3. Guru meminta siswa untuk mengerjakan tugas LKS } \\
\text { dengan melakukan diskusi bersama kelompoknya } \\
\text { masing-masing. }\end{array}$ & 4 & 4 & 4 & 4 & ST \\
\hline \multicolumn{6}{|l|}{ Fase 3: Membimbing penyelidikan } \\
\hline $\begin{array}{l}\text { 1. Guru memberi arahan agar siswa selalu berada dalam } \\
\text { tugas dan bekerja sama dengan kelompoknya. }\end{array}$ & 4 & 4 & 4 & 4 & ST \\
\hline $\begin{array}{l}\text { 2. Guru berkeliling selama kerja kelompok untuk } \\
\text { membantu siswa/kelompok yang kesulitan. }\end{array}$ & 4 & 4 & 3 & 3,7 & ST \\
\hline \multicolumn{6}{|l|}{ Fase 4: Mengembangkan dan menyajikan hasil karya } \\
\hline $\begin{array}{l}\text { 1. Guru menunjuk salah satu kelompok untuk } \\
\text { mempresentasikan hasil kerja kelompok mereka dan } \\
\text { meminta kelompok lain untuk menanggapi. }\end{array}$ & 3 & 4 & 4 & 3,7 & ST \\
\hline $\begin{array}{l}\text { 2. Guru mengarahkan siswa untuk saling bertukar pikiran } \\
\text { (negosiasi) jika terjadi perbedaan pendapat dalam } \\
\text { kelompok. }\end{array}$ & 2 & 4 & 3 & 3 & $\mathbf{T}$ \\
\hline \multicolumn{6}{|l|}{$\begin{array}{l}\text { Fase 5: Menganalisis dan evaluasi proses pemecahan } \\
\text { masalah }\end{array}$} \\
\hline $\begin{array}{l}\text { 1. Guru meminta semua siswa untuk menuliskan } \\
\text { kesimpulan dari hasil diskusi. }\end{array}$ & 3 & - & 3 & 2 & CT \\
\hline $\begin{array}{l}\text { 2. Guru memberi penghargaan kepada kelompok yang } \\
\text { telah mengemukakan pendapatnya. }\end{array}$ & 4 & 4 & 3 & 3,7 & ST \\
\hline \multicolumn{4}{|l|}{$\begin{array}{l}\text { RATA-RATA KEGIATAN INTI } \\
\end{array}$} & 3,6 & ST \\
\hline \multicolumn{6}{|l|}{ C. KEGIATAN AKHIR } \\
\hline 1. Guru mengumpulkan jawaban LKS. & 4 & 4 & 4 & 4 & ST \\
\hline 2.Guru memberikan tugas-tugas atau PR sebagai latihan. & - & 4 & 4 & 2,7 & $\mathbf{T}$ \\
\hline \multicolumn{4}{|l|}{ RATA-RATA KEGIATAN AKHIR } & 3,4 & $\mathbf{T}$ \\
\hline \multicolumn{4}{|c|}{ RATA-RATA KEGIATAN MENGAJAR BELAJAR } & 3,5 & ST \\
\hline \multicolumn{6}{|c|}{\begin{tabular}{|l|l|l} 
II.SUASANA KELAS & &
\end{tabular}} \\
\hline 1. Siswa antutias & 4 & 4 & 3 & 3,7 & ST \\
\hline 2. Guru antutias & 3 & 3 & 4 & 3,3 & $\mathbf{T}$ \\
\hline 3. Kegiatan pembelajaran sesuai alokasi waktu & 2 & 4 & 3 & 3 & $\mathbf{T}$ \\
\hline 4. Kegiatan pembelajaran sesuai skenario pada RP & 3 & 4 & 4 & 3,7 & ST \\
\hline \multicolumn{4}{|l|}{ RATA-RATA SUASANA KELAS } & 3,4 & $\mathbf{T}$ \\
\hline \multicolumn{4}{|c|}{ RATA-RATA PENGELOLAAN PEMBELAJARAN } & 3,5 & ST \\
\hline $\begin{array}{l}\text { PERSENTASE KESELURUHAN } \\
\end{array}$ & & & & \multicolumn{2}{|c|}{$\begin{array}{c}3,5 \\
87,5 \%\end{array}$} \\
\hline
\end{tabular}

Dari hasil pengamatan dan berdasarkan rata-rata pengelolaan pembelajaran diperoleh persentase tingkat keterlaksanaan aspek-aspek pada pertemuan pertama hingga ketiga yaitu sebesar $87,5 \%$ dengan kategori "Tinggi" dan "Sangat Tinggi" sehingga dapat dikatakan bahwa pengelolaan pembelajaran matematika dengan npendekatan realistik dalam model pembelajaran berbasis masalah terlaksana dengan baik. 


\section{Respon siswa terhadap kegiatan pembelajaran matematika dengan pendekatan realistik dalam model pembelajaran berbasis masalah}

Pada umumnya, siswa senang dengan cara guru mengajar yang menggunakan pendekatan realistik dalam model pembelajaran berbasis masalah. Mereka senang mengerjakan tugas-tugas dalam LKS secara berkelompok karena mereka dapat bertukar ide secara bebas dan berdiskusi sehingga membuat mereka cepat mengerti dengan materi yang disajikan. Masalah yang disajikan pada LKS cukup menantang siswa untuk menyelesaikannya dengan benar. Dari angket yang diberikan kepada 40 orang siswa terdapat 36 orang siswa yang memberikan respons positif yaitu sekitar $90,00 \%$.

\section{KESIMPULAN}

Berdasarkan pembahasan hasil penelitian dan ujicoba terbatas dapat diambil kesimpulan sebagai berikut:

5) Perangkat pembelajaran matematika yang dikembangkan dengan pendekatan realistik dalam model pembelajaran berbasis masalah pada pokok bahasan Aritmetika Sosial dalam penelitian ini meliputi:

a Buku siswa,

b Lembar Kegiatan Siswa (LKS), dan

c Rencana Pelaksanaan Pembelajaran (RPP),

6) Pengembangan perangkat ini menggunakan model Thiagarajan atau 4-D (Define, Design, Develop, dan Disseminate)

7) Setelah dilakukan validasi dan revisi sebanyak 2 kali, perangkat pembelajaran yang meliputi buku siswa, LKS, dan RPP ini valid dan layak untuk digunakan berdasarkan hasil penilaian para ahli.

8) Dari hasil ujicoba diketahui bahwa perangkat pembelajaran matematika dengan pendekatan realistik dalam model pembelajaran berbasis masalah bersifat efektif dan praktis, hasil ujicoba diuraikan sebagai berikut:

a. Skor rata-rata yang diperoleh siswa pada tes hasil belajar adalah 70,52 dari skor ideal 100 dengan standar deviasi 15,91. Dimana 28 dari 40 siswa atau 70,00\% memenuhi ketuntasan individu dengan KKM yang ditetapkan oleh sekolah sebesar 60 dan diadakannya remidi bagi siswa yang belum tuntas. Data ini menunjukkan bahwa ketuntasan klasikal tercapai.

b. Dengan menggunakan perangkat pembelajaran dengan pendekatan realistik dalam model pembelajaran berbasis masalah, siswa jadi lebih aktif dalam proses pembelajaran. Hal ini terlihat dari 8 dari 9 kategori aktivitas siswa yang diamati dengan kategori (1), (2), (3), (4), (6), dan (7) yang menjadi syarat utama dalam kriteria memenuhi Interval Toleransi PWI (\%) yang ditentukan.

c. Pada umumnya siswa memberikan respons yang positif terhadap perangkat pembelajaran yang digunakan dengan persentase sebesar $90 \%$.

e. Guru mampu mengelola proses pembelajaran dengan menggunakan pendekatan realistik dalam model pembelajaran berbasis masalah. Hal ini terlihat pada tabel hasil pengamatan pengelolaan pembelajaran dimana sebagian besar aspek dapat terlaksana dengan baik. 


\section{JURNAL SAINTIFIK VOL.3 NO.1, JANUARI 2017}

\section{DAFTAR PUSTAKA}

Asfidah. 2008. Pengembangan Perangkat Pembelajaran Matematika dengan Pendekatan

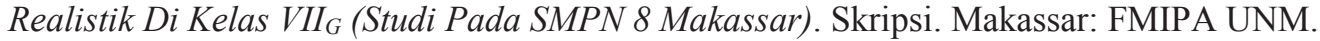

Darwis, Muhammad; Rahman, Abdul. 1999. Matematika Menjelang Era Millenium Ketiga, Jurnal Eksponen, Vol.1 no.3 Januari.

Darwis, Muhammad. 2007. Model Pembelajaran Matematika yang Melibatkan Kecerdasan Emisonal. Disertasi Program Pascasarjana Program Studi Pendidikan Matematika Universitas Negeri Surabaya. Tidak diterbitkan.

Departemen Pendidikan dan Kebudayaan.1994. Kurikulum 1994 Sekolah Dasar.Jakarta: Depdikbud.

Dimyati; Mudjiono. 2006. Belajar dan Pembelajaran. Jakarta: Rineka Cipta.

Hudoyo, Herman. 1990. Strategi Mengajar Belajar Matematika. Malang; IKIP Malang.

Jennings, Sue \& Dunne, R.1999. Math Stories, Real Stories, Real-life Stories.

Slameto. 1995. Belajar dan Faktor-faktor yang Mempengaruhinya. Jakarta: PT Rineka Cipta.

Trianto. 2007. Model Pembelajaran Terpadu dalam Teori dan Praktek. Surabaya: Pustaka Ilmu

Urpiah. 2004. Meingkatkan Kemampuan Penguasaan Matematika Melalui Pendekatan Realistik pada Siswa Kelas V SD Inpres BTN IKIP I Makassar. Skripsi. Makassar: FMIPA UNM

Wijayanti, Pradnyo 1999. Pengembangan Perangkat Pembelajaran Matematika SLTP Untuk Model Pembelajaran Kooperatif Tipe STAD. Makalah. Universitas Negeri Surabaya. 